\title{
Exhibiting Loss and Salvaging the Everyday Photography, Objects and the Missing
}

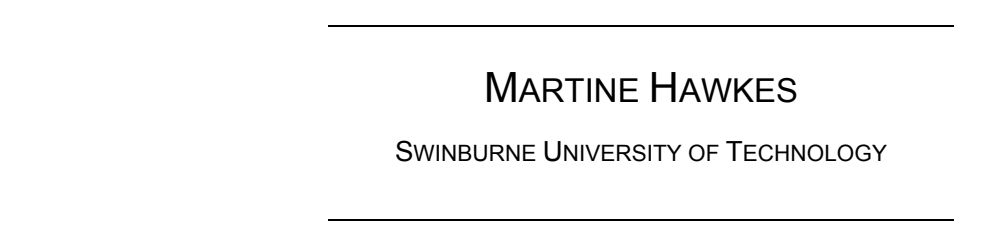

I never miss a single exhumation. He was tall, dressed in a sky-blue T-shirt and green work trousers. I'll recognize him; I'll be able to say goodbye. How long can you go on missing a man you know will never come home again?

Wojciech Tochman, $2008^{1}$

The photographed image of the event, when shown as a photograph, is also part of a cultural construction. It belongs to a specific social situation, the life of the photographer, an argument, an experiment, a way of explaining the world, a book, a newspaper, an exhibition.

John Berger, $1995^{2}$

\section{ISSN 1837-8692}

Cultural Studies Review 2014. @ 2014 Martine Hawkes. This is an Open Access article distributed under the terms of the Creative Commons Attribution 4.0 Unported (CC BY 4.0) License (https://creativecommons.org/licenses/by/4.0/), allowing third parties to copy and redistribute the material in any medium or format and to remix, transform, and build upon the material for any purpose, even commercially, provided the original work is properly cited and states its license. 
-INTRODUCTION

By the end of the conflict in the former Yugoslavia, which took place between 1991 and 1997 and resulted in the deaths of at least one hundred and thirty thousand people, an estimated 22,438 people were unaccounted for. Their whereabouts were unknown and their remains were missing. By 2013, the fate of 14,552 of these individuals had been clarified with 7,886 people still missing. ${ }^{3}$ The clarification of the fate of the missing is a fundamental component of transitional justice processes. Taking as its focus two photographic projects-one with forensic identification purposes and the other with a memorialisation focus-this article will explore the juridical and memorialisation contexts in which these photographs circulate, asking how photographs might be, on the one hand, practical tools for the identification of remains, but also, at the same time, act as visual vehicles for raising awareness and action around the broader justice questions concerning the clarification of the fate of the missing.

The forensic identification photographic project examined by this article is the Books of Belongings. The International Committee of the Red Cross and Red Crescent Movement (ICRC) is a key actor in establishing the fate of the missing by way of ante-mortem data. As part of these activities, in May 2000 the ICRC published the first of its Knjiga Fotografija, or Books of Belongings as the books are known in English. These books contain photographs of the items (clothing and personal effects) recovered from the bodies exhumed from mass graves following the war in the former Yugoslavia. The Books of Belongings are consulted by family members of the missing with the hope that they might recognise photographed items belonging to their missing family members. This initial recognition assists in the task of identifying remains and ascertaining the fate of their family members.

Taking a memorialisation focus are Nick Danziger's photographs of the ICRC identification process, of the recovered belongings, and of the family members awaiting news of the missing. These photographs are displayed in his exhibition The Balkans: Missing Lives. The exhibition was commissioned by the ICRC and since 2010 has travelled around the world and been reproduced in a photographic book titled Missing Lives. ${ }^{4}$

In providing an analysis of both the Books of Belongings and The Balkans: Missing Lives - two collections of photographs produced somewhat in tandem, but 
for different purposes and displayed in different contexts-this article asks how the use of photography might both nuance and play a role in transitional justice processes. In focusing on the photograph as a medium for presenting trauma and particularly on the importance of the context in which the photograph appears, I argue that photography can operate on two levels: first as a practical tool which might assist in the identification of remains and second as a mode of marking the everyday impacts of traumatic event. The first operational level is juridical, while the second performs a memorial function. This article presents the relationship between these two dimensions of transitional justice. But first I offer a broader description of the two photographic collections under discussion.

-ICRC: BOOKS OF BELONGINGS

The Books of Belongings contain photographs of the clothing, jewellery, shoes and other personal items that have been recovered from bodies exhumed from mass graves within the former Yugoslavia. Each item was removed from its body and its grave and photographed individually against a plain white background. The photographs were then presented in book-form, with four photographs printed on each page, surrounded by white space. The Books of Belongings have been used as ICRC tracing tools, allowing family members of the missing to consult the books with the aim of recognising items that may help identify bodies of missing people and ascertain their fate.

Four Books of Belongings have been produced following the exhumation of graves in the region. The first was the May 2000 Srebrenica book, which contains 2,702 photographs of clothing and personal effects found with 473 bodies. This was followed in February 2001 by a book produced by the Organisation for Security and Cooperation in Europe in cooperation with the ICRC, which concerns approximately two hundred bodies recovered in Kosovo in 2000 and contains 750 photographs. In May 2001, the second Srebrenica book was published by the ICRC in collaboration with the International Commission on Missing Persons. This book contains 2,700 photographs of clothing and possessions recovered from 473 bodies. The fourth Book of Belongings, this time concerning the north-west of the Republika Srpska and the Federation of Bosnia and Hercegovina, was published in January 2002. It 
contains 930 photographs of the clothing and belongings recovered from 350 people. 5

These books were published together with the Book of Missing Persons (or The Book of Names), which listed the names of those who were sought. The books were consulted both within the region and by those who had left the region since the conflict. Using photographs of the clothing this way rather than displaying it in identification halls was a response to the scattered nature of the post-conflict populations of the region.

Since first seeing them in the course of my work in the early 2000s, the photographs in the Books of Belongings have never been far from my thoughts. The images of the clothing and personal objects that appear all stand in for a body that has been lost. These items of clothing take on meanings beyond 'my brother's t-shirt' or 'my father's comb'. The photographs of items that appear in the Books of Belongings - each one individually recovered, prepared and photographed-present both the possibility of resolving the question of what happened to a missing person, and the transformation of objects from individual pieces of clothing to items of evidence. In their ordinariness and in their link to an individual (a child's Mickey Mouse t-shirt, a sock with a hole in its toe, a pair of grey trousers), these items may at first give us (the external 'viewer' who is imagining these photographs) the impression that we might know something of the person who existed before the genocide and therefore understand something of the impact of the genocide on one person, on one family. Yet, in its appearance alongside thousands of other photographs of clothing, in its separation from its wearer and in its marks of burial and violence, any comprehension of the life that existed before the genocide is dashed. It is impossible, too, for the external viewer to have any comprehension through seeing the image alone of what it must be like to scan through these photographs searching for something recognisable-or how it might feel when an item is recognised. Nevertheless, these recovered belongings, in their familiarity, do allow for some understanding of the loss that has taken place between the time when these items were somebody's everyday clothes and the present, where these (now) empty shapes tell the fate of the person who wore the clothes.

Photographic identification by way of the Books of Belongings is by no means a definitive or scientific tool for establishing the identities of recovered bodies, but the 
existence of these books tells an important story about the lived experience of those seeking to know the whereabouts of the missing.

These belongings traverse time and space. They were worn, used and held before death, they accompany the body in death and now, stabilised here by the camera, they are recovered and photographed so they can be recognised beyond death. Though apparently retrieved and recovered, these personal items are uninterrupted and mark the continuity of memory. The relationship between the viewer and the photograph is what gives continuity to these images. Without anyone to recognise the items in the photographs, or indeed to recall them in their various contexts, they are arguably simply still and fixed images.

\section{-NICK DANZIGER: MISSING LIVES}

Nick Danziger is a British photographer whose photography is largely concerned with social documentary. Travelling across the former Yugoslavia, Danziger documented the ICRC identification process, the recovered belongings and the family members awaiting news of the missing, resulting in the photographic book, Missing Lives.

The photographs in Missing Lives move behind the statistics and volume of the genocide, and instead show what the family members of the missing endure. They also show the importance of the salvaged or remaining items, as objects that are all that remain of the missing person and that potentially, in the ICRC context, hold one key to their identification. The book and exhibition were also 'designed to serve as a tool to encourage governments and political authorities in the Balkans and across the West to commit to solving more cases at a faster pace to alleviate families' suffering' and to show how import these salvaged personal objects are to families. ${ }^{6}$

Four of Danziger's photographs presented in Missing Lives tell us of Dzidza Mehmedović, whose two sons Almir and Azmir went missing during the Srebrenica genocide. From the accompanying text, we learn that some years after the genocide Dzidza was able to return to her family home and, finding it burned, wished to recover from there something that belonged to her children. On page 111 of Missing Lives is photograph of Dzidza's hand. Her hand takes up the whole frame of the photograph with the surrounding background out of focus. In the centre of her open palm is a glass cats-eye marble that belonged to her sons; one of the few items that 
she recovered from her destroyed house. The skeleton of one of her sons was recovered in one of the mass graves shortly before this photograph was taken, but at the time of the photograph the DNA results had not been conclusive about which son the skeleton belonged. Dzidza told Danziger: 'I know that their remains have been found. But in my heart I still believe that my boys might come home for dinner.'7

The use of personal belongings is already a familiar way of representing genocide in museums-think of the piles of shoes in Holocaust museums. These items testify to the mass, to the volume of victims. They are also items that the perpetrator, the executioner, collected. James E. Young writes: 'That a murdered people remains known in Holocaust museums anywhere by their scattered belongings ... that their lives should be recalled primarily through the images of their death, may be the ultimate travesty.' 8 The collection of shoes becomes a travesty because, unlike those items that we might hold onto from missing loved ones as a precious last reminder, these items were retained on the order of the killers of these people, killers who valued lives less than the potential value of shoes.

The photographed belongings discussed here are those collected post-genocide as part of the identification process. Because of their use in this process, they are individually separated out so they can be matched to a missing person. It is the photographic process that enables each item to be individualised; to be examined as one item distinct from the others; to allow the family of the missing to be photographed with the recovered object and sustain the possibility of a personal connection to the items. These objects, photographed and printed, are reminders of the individual life more than remnants of the death. In Danziger's photograph of Dzidza, we are shown one marble. Though this one marble, we might think of this one death and in this one death we might better understand what it might mean to feel loss.

\section{-THE PHOTOGRAPH AND THE VIEWER: WHO IS LOOKING?}

The photograph and what it is representing is, in its primary meaning, direct. The image of Dzidza and the marble is of a hand with a marble on its palm captured at a particular instant in time. While interventions occur-the photograph is staged and, once taken, is reproduced-the instant (the time, the place) at which Dzidza's hand held the marble and was photographed is fixed. 
Beyond saying that we are looking at an image of a hand holding a marble, it is not possible for us to arrive at a reliable narrative by the image alone. We may look at this photograph and guess at the story it is performing, but in the photograph there is only reflection and portrayal. On to this we may layer our own stories, but for the context and the true narrative of the image to emerge, we require words to accompany the photograph and we also require the broader context in which they are exhibited.

Viewing these photographs requires not just an understanding of their visual contents, but also an understanding of their particular context. Danziger's photographs are accompanied by text and do not stand as images without context. The photograph of Dzidza holding the marble appears in the book alongside text by Rory Maclean that explains Dzidza's memories of her sons, the significance of the marble to these memories and her experience of the identification processes.

However, there is a danger that photographs such as these which attempt to show us something of the experience of genocide can become what Mark Durden, in his writing of the media's depiction of Afghanistan, terms 'a spectacle of ruins'. ${ }^{9}$ The viewer, removed from the trauma that is depicted or described, becomes voyeur. But this is not a passive or neutral position. There is a way of looking that Nancy K. Miller in writing of the 1972 photograph of Kim Phuc running away from a napalm strike in Vietnam calls 'the civilian gaze'; 10 a way of looking in which we are at once safely removed from the event, but also complicit in it through our position of safety.

The photographs in the ICRC Books of Belongings are of another order of photography. They are in a sense utilitarian, their primary purpose to assist in identification. These photographs are presented and used as vehicles to establish the identity of the body through particular objects or items of clothing. They tell us that this pair of trousers or that bracelet was found in a particular mass grave. In using these images for identification purposes, it is possible to discover to whom the objects belonged, thereby helping establish the identity of a body found in the grave.

The apparent stability of how photographs in the Books of Belongings can be read comes about because they are presented in a context that leaves no confusion about their purpose or their intended viewers (who are clearly not 'civilian gazers'). The images are not publicly accessible; they can only be viewed by affected communities. If they were shown in another context, the same images might be 
layered with another narrative and be open to becoming 'spectacle'. Paul Williams writes of photographs taken of those who arrived at the Khmer Rouge Security Prison 21 in Phnom-Penh, Cambodia (now the Tuol Sleng Museum of Genocide) before they were executed there. The photographs were taken between 1975 and 1979. Many of the photographs are now displayed on the walls within the Tuol Sleng Museum, which was opened in 1980.

In 1997 some of the photographs from Tuol Sleng were exhibited at New York's Museum of Modern Art. Williams notes that removed from the Tuol Sleng Museum, where the images are displayed within the context of the site where the killings took place and the context of a genocide memorial and museum, 'the photographs on exhibit generally were received and critiqued as fine art'.11 If the photographs presented in the Books of Belongings were exhibited outside their original context, they would move from having a strict identification (and justice) purpose to having an aesthetic purpose.

Danziger's photographs, which depict the experience of the families of the missing, perform a dual function: memorial and aesthetic. The photograph of Dzidza holding a marble, without its context, shows us nothing more than a hand holding a marble. Even with its context given, it is absolutely receivable as art, as a photograph with its primary purpose being visual.

While photographic images fix a moment in time and allow for processes of identification and comparison to occur, unless they have a context they cannot move beyond their primary depiction. Berger writes:

In the relation between a photograph and words, the photograph begs for an interpretation, and the words usually supply it. The photograph, irrefutable as evidence but weak in meaning, is given a meaning by the words. And the words, which by themselves remain at the level of generalisation, are given specific authenticity by the irrefutability of the photograph. Together the two then become very powerful; an open question appears to have been fully answered.12

In the case of the photograph of Dzidza's hand holding the marble, the photograph is accompanied by a caption, and so we are provided with the following context: 'All of Dzidza's possessions were stolen, burnt or lost. On her return home all she found was a school exercise book and one of her son's marbles in the rubbish tip.'13 From 
this we are not told the historical context of Dzidza's loss, but this is provided by the exhibiting of this photograph in the exhibition 'Missing Lives' and in the book by the same title, which as a collection provides us with the context via captions, lengthy narratives, and introductory essays. We are told in the text accompanying the book and the exhibition of the history of the war in the former Yugoslavia, in which Dzidza's sons came to be missing, and also of the identification processes.

Sonja Fessel, writing of Bart Michiels's photographs of apparently neutral landscapes published in The Course of History writes:

[Michiels's photographs] show spacious landscapes or close-up details in nature-some romantically beautiful, others sombre and desolate ... No human activity is depicted, no architectural elements appear, and only rarely do hints of time and place mark these images. Only by reading the titles of individual photographs does the viewer become aware of his mistake: almost inevitably, one is seduced into perceiving these photographs as 'pure' landscapes. In fact, they reveal themselves to be the sites of some of the most violent battles in European history. ${ }^{14}$

We could also add that reading these photographs, even after seeing the titles, is therefore not limited to the time of the historical context that the titles offer. In looking at Michiels's landscapes we can wonder what has happened in this landscape since its violent history; to what use (if any) is the landscape now put? Did it look much like this before the battle? In Danziger's representation of one woman-of her hand holding a marble-the lives that lived this history are placed in the foreground. This history, the context for this photograph, then becomes unfixed. The marble that Dzidza holds shows us the trace of life before history intervened, her holding it now shows us that life for Dzidza has continued after the interventions and excisions of this history.

\section{—MEMORY AND JUSTICE: THE FUNCTION AND CONTEXT OF PHOTOGRAPHY}

Danziger's photographs represent the memorial dimension of transitional justice. The photography that allows for identification and comparison plays a legal role in transitional justice processes, but it is the affective dimension of Danziger's photographs that enables memorialisation to take place. Photographs such as these allow for an understanding of the ongoing lived experience of the loss. I propose, 
following Marianne Hirsch and Leo Spitzer in their reading of the discursive texts of witness testimony where they highlight 'visuality and especially photography as privileged media of memory', that such photographs play an invaluable role in shaping an understanding of the possible dimensions and interests of transitional justice. ${ }^{15}$

The memorial dimension of transitional justice visible in photography captures something of the everyday existence of a person who has experienced loss. The everyday experience of 'knowing someone' is lost through genocide, but it is also lost in the structures of the post-genocide responses. These are those responses, such as justice procedures, monuments and remembrance days, through which the everyday experience of having known someone and of having lost someone is overshadowed by the broader documentation of the genocide. The familiarity of the everyday, its universality, remembers what cannot be recaptured and attempts to approach the individual, to provide a link to them, through these everyday, familiar experiences. To remember and do justice for the boy playing marbles and for his mother living with what remains rather than with the boy who was killed; this is surely what might give energy to other transitional justice efforts.

In the Books of Belongings and Danziger's photographs we see two collections of photographs that allow for another side of both loss and transitional justice to be performed. But the collections were produced for quite different audiences, contexts and purposes. Because of this, I now turn to the question of how these photographs of everyday objects might impact on wider politics and international policymaking in the region. How, with their display, might a new emphasis be placed on how survivors continue to remember loved ones? I present, in the ICRC and Danziger photographs, a blurring of the word 'exhibit'.

The Books of Belongings have a clear juridical purpose. The photographs are vehicles for displaying clothing and belongings for identification purposes. Here, the photography and their display within the book are exhibits with a purpose: to clarify the fate of the missing. They are not 'on show' or publicly available to people outside the ICRC identification process. Their remit and use is clear.

In both the Danziger and the ICRC photographs we see private moments and private objects. In many of Danziger's photographs we see the hand of a family member holding the object or the family photograph of the missing person. In the 
ICRC photographs, each personal item is separated from the mass for the eyes of the family member who might find a familiar item among the images. The difference is that the ICRC identification process is mediated by ICRC workers and Danziger's images are presented to a general public in the form of an exhibition and published book.

In his note on Danziger's photographs, Pierre Krähenbühl, ICRC director of operations, states:

Behind the many statistics and statements, there are individual men, women and children whose lives were torn apart by untold violence. It is a fundamental issue of dignity that the thousands of affected families receive news and support. It remains as urgent as ever to elucidate the fate of their missing loved ones. ${ }^{16}$

Danziger's book and exhibition, while depicting the everyday experience of loss, are also intended to encourage a government commitment to clarifying the fate of the missing in the former Yugoslavia. ${ }^{17}$ In contextualising the photographs within an exhibition space in particular, there is a mediation that takes place that has an impact on the ability of this aim to be realised.

The display of the photographs in an exhibition space or in a book lends, for the viewer of these images, a stabilising effect to the losses and the trauma that they are viewing. The exhibition space acts as an intermediary between the viewer and the event. It does not let us get too close. It puts up glass, it provides textual explanation, it is branded with the ICRC logo, and we are welcomed and directed by docents and guides. The exhibition space, in providing certain protocols, provides context. We are presented with the events in capsule-form. Each of the stories presented by Danziger bears a resemblance to the last. On receiving these stories, one after the other, we are left with a clearer and accumulatively traumatic narrative of the experience of living with loss in this context. This effect on viewers is essential if Danziger is to achieve the kind of awareness-raising that he has set out to produce through his photographs.

However, as Martha Minnow, writes of transitional justice processes: 'Saying that context matters is not the end of analysis. Rather it is the beginning.' ${ }^{18}$ Here we might understand that while context does not inform the entirety of our understanding, we must pay close attention to it. I note that the context of the 
exhibition is not so dissimilar to the context of the legal space in its coded behaviours, protocols and procedures, but also in its privileging of a particular kind of testimony. While the testimonies that Danziger presents are not provided with space or time in the courts and, as I will go on to argue, his photographs show us something crucial about the transitional justice process, it is the context in which they are displayed that is of interest here.

In the context of a court, photographs hold the potential to have a clear justice impact. Richard Wright, who worked as a forensic archaeologist in the mass graves holding the bodies of those killed during the Srebrenica genocide, tells how the use of two photographs of such bodies proved more powerful than his own words during his appearance at the International Criminal Tribunal for the former Yugoslavia (ICTY) in February 2007:

I insisted that I had not seen an item of military clothing on the 2000-3000 bodies my team had exhumed. I insisted that I was not mistaken in seeing high numbers of blindfolds and arms tied behind the back. Words, words, words from both myself and the defense team of barristers. In his right of reply the prosecuting barrister said nothing; he simply put up two photos on the court's screen. They were the photos from my official report of a man in civilian clothes, who had broken the ligature fixing his hands behind his back, slipped his blindfold down, and grasped a shrub at the moment of death. The prosecuting barrister asked me a single question. Were these photos the sort of evidence that led me to my conclusions. I said yes. The prosecuting barrister said he had no more questions for me. I think that the photos of a body cut through the verbiage of the courtroom, effectively arresting the defence efforts to reinterpret the evidence. ${ }^{19}$

The photographs-or rather, the items and events that they capture and fix-testify to the events of the genocide in the context of the ICTY. In testifying to the everyday experience of loss, and the calls for more resources and emphasis to be placed by governments on the clarification of the fate of the missing, the photographs in the Books of Belongings and Danziger's photographs both have roles to play, as Wright hints in his testimony.

The photographs in the Books of Belongings have a very specific role in the justice process. The identification of clothing or objects found on a body recovered 
after genocide forms a support for the identification of remains. It is a complementary aspect of identification alongside the matching of ante-mortem and postmortem dental and skeletal radiographs, fingerprints, DNA samples and the matching of particular physical or medical identifiers. Arguably, these photographs are of the most private and intimate of remnants.

However, clothing remains a crucial identifier in the many cases where other forms of identification are not available. In their guidelines for the identification of dead bodies, the Pan American Health Organization, the World Health Organization, and the ICRC note that photographing clothing found on the body is mandatory where photographic equipment is available. Together with the photographs, a record is made of all personal belongings such as jewellery, clothing and identity cards. ${ }^{20}$

The photo identification offered by the Books of Belongings is by no means a definitive or scientific tool for establishing the identities of recovered bodies, but the ordinariness and familiarity of the clothing tell stories both of the life before the death and of the fate of the body that cannot be told through other means of identification. The existence of these books also tells a story of the lived experience of those who are seeking to know the whereabouts of the missing.

Because they appear in an exhibition, Danziger's photographs-many of which depict objects that also appear in the Books of Belongings-move from being documentary or clearly justice-driven to being unstable in their possible interpretations. Danziger's exhibition allows engagement in discussions triggered by the images on display that moves the photographs beyond the walls of the exhibition, but transforming such conversations into the kind of action the ICRC describes in its support of Danziger's photographs is difficult. These photographs on the one hand function as awareness raising images, but on the other hand are open to artistic critique in their display in an exhibition. I wonder about the impact of the strictures and structures of the exhibition space on the ability of these photographs to achieve the aims set out by Danziger. The exhibition may be responsive to the transitional justice processes and portray the loss and the memory of the missing, but context certainly matters. To consider further the role and the context of these photographs, I now frame their place and importance, and that of the objects depicted in them, within a broader justice context. 
One of the stated aims of the ICTY is to establish a historical record of the events of the war in the former Yugoslavia. ${ }^{21}$ The ICTY will doubtless produce a historical record of these events, but it will be a historical record that is limited and determined by the court, rather than by the ongoing effects of what took place and the impacts on survivors of missing or losing people close to them. What is not represented and not responded to in the court is the lived experience of the event and of the post-event present. ${ }^{22}$ The fate of the missing may be attended to by the courts through efforts to establish the location of graves, but if space for the ongoing experience of missing somebody is not allowed, if the memory is treated as distinct from the justice process, then the priorities of the court may not be in accord with those the court serves.

The focus of the ICTY is on the past-the facts of the event-and the future, through the possible outcomes and impacts of the court's production of a historical record in particular. This is accompanied by an ignorance of the present, particularly of the lived experience of the genocide and the broader societal after-effects of the genocide that those victim-witnesses now live with.

The experience of living with the present-day effects of the event and the pressure to testify is outlined by Ed Vulliamy, who tells the story of Sija, a woman who returned to live in Srebrenica after the genocide:

As she speaks, a man walks by the window, checking electricity meters. 'He is doing that now,' says Sija, 'but during the war he was burning houses. I know they killed my husband and my son. I know that my neighbours were involved in this. But you can't say this one burned that house and that one killed that man-they were all involved. They wanted me to go to The Hague, but my daughter said people here would kill me, and I didn't. So I don't talk to them. They have their life, I have mine. If I cry, I would die of heartbreak, so I don't. Instead, I fix my house, I eat something, I drink some coffee.'23

Eric Stover, in his study of witnessing at the ICTY, notes that for many of those who experienced losses in the conflict in the former Yugoslavia, the notion of justice is strongly tied to their lives and well being in the present: 
[Justice] means returning stolen property; locating and identifying the bodies of the missing; capturing and trying all war criminals, from the garden variety killers in their communities all the way up to the nationalist ideologues who had poisoned their neighbours with ethnic hatred; securing reparations and apologies; leading lives devoid of fear; securing meaningful jobs; providing their children with good schools and teachers; and helping those traumatized by atrocities to recover. ${ }^{24}$

This is a justice that responds to the everyday present life of Sija. The following excerpt from an ICTY transcript is an example of the continuing movement, intrusion and incorporation of the past event in the present life and the collision or mingling of this present and past within the accounts given in the courtroom:

Judge Riad: [Interpretation] Have your neighbours changed their attitude towards you, or do they still have friendly feelings towards you? I'm talking about your Serb neighbours.

A.: You mean up to the time they took my child? You mean the neighbours I recognised?

Judge Riad: [Interpretation] Yes, and the others.

A.: I noticed him, and I saw that he could recognise me, too, because he cast a quick glance at me ... I thought that I should scream out for him to save my child, but then I thought better of it because I had heard from others that the neighbours were doing the worst thing and so I thought maybe my child would [fare] even worse, so I restrained from addressing him.

Judge Riad: [Interpretation] And so you have no Serb neighbours around you; you don't visit one another at all?

A.: Probably there are some, but I have no contact with them. Simply we don't communicate. How do I know?25

In this transcript, the account of the witness becomes reduced and refined. The connection between the present and the past is severed by the judge. ${ }^{26}$ The focus seems to be on refining the account of the witness to the point of confusion about what the desired answer is ('Probably there are some ... How do I know?'). While this is a rare excerpt in that it does make reference to how life is now, it is a 
bewildering reference, as it seems to be removed from its informing past, particularly in the section in which Judge Riad asks the witness, whose child was taken and killed by his or her neighbours, 'you don't visit one another at all?' MarieBénédicte Dembour and Emily Haslam in their analysis of victim-witnesses at the ICTY describe an exchange between Judge Riad and another witness. The witness, after complaining of the inability of many people in Bosnia, including himself, to now return to their pre-war houses, is wished a happy return home: 'It is as if the judge has not heard anything that the witness had tried to say.'27

A justice process that focuses on resolving the facts of the war and genocides but which is not responsive to present day needs is dangerously lopsided. In their editorial note to the July 2012 issue of the International Journal of Transitional Justice, Helen Chang Mack and Mónica Segura Leonardo write:

Much of the discussion on transitional justice centers on ways of dealing with political killings and other atrocities of the past ... The danger, however, is that emphasizing these larger questions can obscure some of the more 'mundane' issues that face the nation, including the high levels of 'ordinary' crime. A focus on the 'big' questions of transitional justice also obscures the links between crimes committed during the war and the high crime rate in the present. 28

Danziger's photographs are not explicitly focused on the criminal activity that often thrives after conflict of the type Mack and Leonardo are discussing, but the photographs are highlighting an aspect of transitional justice that is often dismissed when we think of transitional justice processes. A focus on criminal prosecutions for genocide and crimes against humanity, and the establishment of the broader history of what took place at the time of the conflict, perhaps makes it easy to elide the everyday experiences of living post-conflict, which might include seeking justice for the personal experience of loss, the wish to return to a house, the need to know where a body is buried, a desire to have the remains returned for burial. The postconflict experience also demands a temporal shift in the dominant understanding of transitional justice, which is often aimed at addressing only facts from the time of the conflict, with little interest in the continued impacts of that conflict.

In Danziger's images of those awaiting justice in their present lives, in the demonstration of injustices not being simply fixed to a time in the past, is a call for a 
justice that is responsive to the present lives of those photographed by Danziger and those searching for (or indeed hoping not to find therein) familiar items in the Books of Belongings.

When I write here of a 'call' for justice, I wish to emphasise the relationship between memory practices such as Danziger's photography exhibition and the formal justice processes such as the ICTY. Elizabeth Jelin writes: 'Much of the literature on transitional justice sets apart institutional and symbolic measures. This is a false distinction from the perspective of the main actors, the victims, as well as the national community more generally.'29 Indeed, that the justice institutions make use of objects similar to those photographed by Danziger in their trials demonstrates that something of a dialogue around the personal importance of these objects to the surviving family needs to take place. This dialogue is also around ensuring that the justice emphasis and desires of the courts is in concert with those of the people for whom justice is being sought.

To arrive at the truth of what took place in the former Yugoslavia, many objects such as those photographed by the ICRC for forensic identification after being recovered from the bodies of those who are missed by the people photographed by Danziger have been used in the ICTY. They have been used, for example, to determine that these graves contained civilians rather than combatants.

In 2009 it came to light that between the years 2005 and 2006 more than one thousand artefacts used in the course of the trials, including objects recovered from mass graves, were destroyed by the ICTY. The ICTY claimed the reasoning behind this destruction was because these items were no longer needed for the proceedings and that they presented a health risk. ${ }^{30}$

But the use of these objects did not end when the person to whom they belonged was killed and their use does not end when the object has served its identification and justice purposes. Whether families were awaiting the return of these objects for burial is not recorded by the ICTY. However, the photographs of these objects remain. This is perhaps where we meet the limit of photography and can ask questions about whom these photographs are for. Many of Danziger's photographs are of family members holding photographs of their missing relatives which were taken before the war. But photographs of these objects and clothing, and the capturing of the interaction and relationship with these items, is not the same as 
having the object itself. Fixing the objects in a photograph also fixes them in time, leaving no ongoing physical trace or remnant of the missing. Perhaps there is also something in this 'fixing of time' that contradicts the progressive narrative in which the objects are recovered, photographed, identified and discarded.

The photographs of these objects present a temporal contradiction or disruption in the progressive narrative of the event. The photographs and the relationship between the objects and the surviving family members exposes, as Ulrich Baer in his writing on the photography of trauma writes, 'as a construction the idea that history is ever-flowing and preprogrammed to produce an on-going narrative'. ${ }^{31}$ At first glance the photographs show the continuity of the missing. The objects in the photographs seem to sew together the memory of the lives before the genocide and the lives of the families after the event. In an image in one of the Books of Belongings it is possible to see an item (a comb, a cigarette lighter, a jumper) which circulated in an everyday and ordinary way before their owner was killed or went missing. However, it is also possible to see in these photographs that these items bear the mark of death and loss-the damp and damage from the grave as well as from the brutality of the death, or, in the case of the marble recovered from a burned house, significance in the fact it remained intact while all else was destroyed. If her sons were not missing, this one marble may not have such significance, let alone be retained.

The temporal contradiction occurs because we are taken in one photograph to a time before the genocide. The item of clothing in the photo is significant because it was worn before the genocide. The photograph also takes us to the genocide itself. The item of clothing shows the marks of death and burial. The photograph takes us too to the time when the object was recovered and identified or prepared for photography. There is no sequence or flow; rather, there is persistence. These items of clothing and objects come from both before the death, but they bear the mark of death-dissolving any possibility of the object serving solely to remind one of the past (though they do this too). They disrupt temporality and speak to the experience of loss. The images span the time with no pause. Though apparently lost and then recovered, these clothes and objects have existed uninterrupted.

While there is indeed loss and rupture, there is no pause; in their singling-out by the photograph (the photograph of both the individual object and of the family 
who is missing the person), we perhaps can see afresh that the life of this missing person continues without pause because they have been sustained and are transported by memory from the time before the genocide to the present day.

Dzidza's memory of her sons playing with marbles is by no means unfinished or fragmentary. Though interrupted by destruction and war, her memory is not interrupted by gaps. The memories of objects and events and relationships presented by Danziger invalidate the assumption that we are-in our viewing of Danziger's photographs, in our showing of the Book of Belongings-somehow retrieving that which was irrecoverably lost or destroyed. It is precisely the fact that our attention is called to, for example, this marble and the specificity of the memory of which it is composed, that tells us something crucial about the genocide which was, at the time the marble was being played with, at the time the clothing was worn, still to come.

This article is only able to approach the lives and their losses presented by Danziger because they are marked and present, vocalised and captured by the surviving family members. The losses are 'fixed in time' by the camera. They are further fixed by the opening hours or location of an exhibition, of their publication within a physical book. It might be argued that this fixing and archiving has something in common with the kind of focus that takes place in transitional justice processes, which privilege archiving and the permanent record. In transitional justice processes, the complexities of cultural memory are apparent. We see the aims of the ICTY, a body charged with carrying out the criminal procedures, expanding out to include the desire to also be responsible for establishing the historical record of the conflict in the region. However, a legal space-especially one which is constrained by time-will by necessity exclude those narratives of the everyday, which tell us what life was like before the conflict and what life is like now.

Danziger's marking of the dead is given space in art galleries and in the institutional support offered to his photography by the ICRC. But what is being archived by Danziger's camera is that which is unrecordable in the broader transitional justice processes. Danziger's marking of the dead shows the complexity and continuity of absence. In photographing the people and objects once held by now absent hands, Danziger demonstrates that there is no incompleteness or 
interruption to the everyday experience of remembering that is being bridged or brought to life here. Photographs hold time; they hold and remember the loss. Courts do not have the time.

We are speaking here, after all, of the performance of memory, by way of the physical remnant, of a connection to the life that has been lost and this must be revered. Pierre Nora writes: 'The sacred is invested in the trace that is at the same time its negation.' 32 The objects photographed by the ICRC and Danziger's images of family members holding these objects are sacred. Yet, as can be seen in the original damage done to these objects and in their destruction at the ICTY, within this trace is the possibility of doing damage to memory.

These photographs demonstrate continuity and discontinuity through a simultaneous absence and presence. The photograph of the marble and the photographs of the recovered clothing and objects enable a comprehension that is in turn erased, displaced and dissipated. After all, the material objects depicted in the photographs are subject to consumption, decay and wear as their meanings shift. The photograph artificially fixes them in time, creating another object-the photograph. And yet they persist. The clothing and the objects persist through their familiarity from a time before the genocide and its physical reappearance here in the present, bring something of the life-of the person-who wore the clothes and held and used the objects.

The remembering that is taking place here-by those photographed by Danziger and those who look at the Books of Belongings-is not the uncomplicated reminiscence of a past that has slipped away, it is not the ever-flowing historical narrative that Baer resists. Homi K. Bhabha writes: 'Remembering is never a quiet act of introspection or retrospection. It is a painful re-membering, a putting together of the dismembered past to make sense of the trauma of the present.' 33 And so the photographs of the clothing and the objects allow both a remembering of the past, a re-membering of the person as they were in life, and within this a framing of the impact this past has upon the present and future.

\section{-CONCLUSION}

The clarification of the fate of the missing is surely one of the most crucial aspects of transitional justice processes. Resolving their whereabouts is simultaneously the 
impetus and the purpose of such processes. In the presence of the photographs discussed here-in the way they record and retain the image of the objects in the Books of Belongings and tell of the relationship between these objects and the memory of those who are missing someone in Danziger's photographs-the presence of the missing is reasserted. In singling out objects, it becomes possible to see each item as belonging to one missing person and to understand that beyond their more sequential and linear forensic and justice potential, these belongings also have significance for keeping the memory of the missing person. In their focus on individual experiences of missing someone, the images are readable as an individual narrative. It is not easy in records of the broader historical event alone to imagine individual loss. Viewing images such as these alongside the broader record allows us to imagine this loss and, therefore, to understand how important it is that the fate of the missing be resolved.

Martine Hawkes is a social researcher. Her research interests centre on the politics of international interventions, historical justice and social constructions of memory after loss.

\footnotetext{
-ACKNOWLEDGEMENTS

I wish to thank and acknowledge the reviewers of this article for their insightful and constructive suggestions.

-Notes

${ }^{1}$ Wojciech Tochman, Like Eating a Stone: Surviving the Past in Bosnia, trans. Antonia Lloyd-Jones, Portobello Books, London, 2008, p. 129.

2 John Berger, Another Way of Telling, Vintage Books, New York, 1995, p. 93.

3 'Bosnia and Herzegovina: Families of Missing Persons Pursue their Quest', ICRC, 28 August 2013, <http://www.icrc.org/eng/resources/documents/feature/2013/09-28-bosnia-herzegovinadisappeared-missing.htm>.

${ }^{4}$ Nick Danziger and Rory MacLean, Missing Lives, Dewi Lewis Publishing and ICRC, Stockport UK, 2010.
} 
5 ICRC, Unknown Fate, Untold Grief: ICRC Activities on Behalf of Missing Persons and their Families from the Conflicts in Croatia, Bosnia-Herzegovina and Federal Republic of Yugoslavia/Kosovo, ICRC Special Report, August 2002, <https://www.icrc.org/eng/assets/files/other/sr_balkans_missing.pdf>.

6 'Missing Lives: Book and Photo Exhibition', ICRC, 6 July 2010,

<http://www.icrc.org/eng/resources/documents/misc/missing-lives-060710.htm>.

7 Danziger and MacLean, p. 110.

8 James E. Young, The Texture of Memory: Holocaust Memorials and Meaning, Yale University Press, New Haven, 1993, p. 133.

${ }^{9}$ Mark Durden, 'The Poetics of Absence: Photography in the "Aftermath" of War' in Paul Seawright (ed.), Hidden, Imperial War Museum, London, 2003, unpaginated.

${ }^{10}$ Nancy K. Miller, 'The Girl in the Photograph: The Visual Legacies of War', in Geoffrey Batchen, Mick Gidley , Nancy K. Miller, and Jay Prosser (eds), Picturing Atrocity: Photography in Crisis, Reaktion Books, London, 2012, p. 148.

11 Paul Williams, 'Witnessing Genocide: Vigilance and Remembering at Tuol Sleng and Choeung Ek', in Holocaust and Genocide Studies, vol. 18, no. 2, 2004, p. 244.

12 Berger, p. 92.

13 Danziger and MacLean, p. 110.

14 Sonja Fessel, Simon Schama and Bart Michiels, Bart Michiels: The Course of History, Damiani, Bologna; Sonja Fessel, 'The Absence of Atrocity: Bart Michiels's The Course of History Photographs', History of Photography, vol. 18, no. 3, 2012, p. 315.

15 Marianne Hirsch and Leo Spitzer, 'The Witness in the Archive: Holocaust Studies/ Memory Studies',

Memory Studies, vol. 2, no. 2, 2009, n. 2.

16 'Missing Lives: Book and Photo Exhibition'.

17 'Missing Lives: Book and Photo Exhibition'.

18 Martha Minnow, Between Vengeance and Forgiveness, Beacon Press, Massachusetts, 1998, p. 4.

19 Richard Wright, 'Where are the Bodies? In the Ground', The Public Historian, vol. 32, 2010, p. 105.

20 ICRC, PAHO, WHO, IFRC, Management of Dead Bodies after Disasters: A Field Manual for First Responders, PAHO, Washington, 2009, p. 16.

21 ICTY, Address by Chief Prosecutor Carla Del Ponte at the Conference on 'Establishing the truth about war crimes and conflicts', CADEL/STAT070215, 2007.

22 For more discussion of the role of the ICTY in relation to the lived experience of victim-witnesses, see Martine Hawkes, 'Containing Testimony: Archiving Loss after Genocide', Continuum, vol. 26, no. 6, 2012, pp. 935-45.

${ }^{23}$ Ed Vulliamy, 'Afterword' in Emir Suljagić, Postcards from the Grave, Saqi Books, London, 2005, pp. 192-3.

${ }^{24}$ Eric Stover, The Witnesses: War Crimes and the Promise of Justice at the Hague, University of Pennsylvania Press, Philadelphia, 2007, p. 15. 
25 The Prosecutor v. Radislav Krstić, Case IT-98-33, open session 26 July 2000, ICTY.

26 The judge is, I note, following the court protocol. It is this protocol that enables such severance-and, indeed, which makes anything other than this severance impossible, counter to its rules.

27 Marie-Bénédicte Dembour and Emily Haslam, 'Silencing Hearings? Victim Witnesses at War Crimes Trials', European Journal of International Law, vol. 15, no. 1, 2004, p. 172.

28 Mónica Segura and Helen Chang Mack, 'Editorial Note: When Transitional Justice Is Not Enough', International Journal of Transitional Justice, vol. 6, 2012, p. 175.

${ }^{29}$ Elizabeth Jelin, 'Public Memorialization in Perspective: Truth, Justice and Memory of Past Repression in the Southern Cone of South America', International Journal of Transitional Justice, vol. 1, 2007, p. 156. 30 'Weekly Press Briefing', ICTY, 15 July 2009, <http://www.icty.org/sid/10185/en>. For an extensive analysis of the 2005-2006 destruction of artefacts at the ICTY, including refutation of the ICTY's reasons for their destruction, please see Olivera Simic, 'Memorial Culture in the former Yugoslavia: Mothers of Srebrenica and the Destruction of Artefacts by the ICTY' in Peter Rush and Olivera Simic (eds), The Arts of Transitional Justice: Culture, Activism, and Memory after Atrocity, Springer Series in Transitional Justice, vol. 6, Springer, London, 2014.

31 Ulrich Baer, Spectral Evidence: The Photography of Trauma, The MIT Press, London, 2002, p. 1.

32 Pierre Nora, 'Between Memory and History: Les Lieux de Mémoire', Representations, vol. 26, 1989, p. 14.

${ }^{33}$ Homi K. Bhabha, The Location of Culture, Routledge, London, 1994, p. 63.

\section{-Bibliography}

Baer, U., Spectral Evidence: The Photography of Trauma, The MIT Press, London, 2002.

Berger, J., Another Way of Telling, Vintage Books, New York, 1995.

Bhabha, H. K., The Location of Culture, Routledge, London, 1994.

Danziger, N. and R. MacLean, Missing Lives, Dewi Lewis Publishing and ICRC, Stockport UK, 2010.

Dembour, M-B., and E. Haslam, 'Silencing Hearings? Victim Witnesses at War Crimes Trials', European Journal of International Law, vol. 15, no. 1, 2004. doi: http://dx.doi.org/10.1093/ejil/15.1.151

Durden, M., 'The Poetics of Absence: Photography in the "Aftermath" of War' in Paul Seawright (ed.), Hidden, Imperial War Museum, London, 2003.

Fessel, S., 'The Absence of Atrocity: Bart Michiels's The Course of History Photographs', History of Photography, vol. 18, no. 3, 2012.

Hawkes, M., 'Containing Testimony: Archiving Loss after Genocide', Continuum, vol. 26, no. 6, 2012.

Hirsch, M., and L. Spitzer, 'The Witness in the Archive: Holocaust Studies/ Memory Studies', Memory Studies, vol. 2, no. 2, 2009.

ICRC, Unknown Fate, Untold Grief. ICRC Activities on Behalf of Missing Persons and their Families from the Conflicts in Croatia, Bosnia-Herzegovina and Federal Republic of Yugoslavia/Kosovo, ICRC 
Special Report, August 2002,

https://www.icrc.org/eng/assets/files/other/sr_balkans_missing.pdf.

ICRC, 'Bosnia and Herzegovina: Families of Missing Persons Pursue their Quest', ICRC, 28 August 2013, http://www.icrc.org/eng/resources/documents/feature/2013/09-28-bosnia-herzegovinadisappeared-missing.htm

ICRC, PAHO, WHO, IFRC, Management of Dead Bodies after Disasters: A Field Manual for First Responders, PAHO, Washington, 2009.

ICTY, Address by Chief Prosecutor Carla Del Ponte at the Conference on 'Establishing the truth about war crimes and conflicts', CADEL/STAT070215, 2007.

ICTY, 'Weekly Press Briefing', ICTY, 15 July 2009 http://www.icty.org/sid/10185/en.

Jelin, E., 'Public Memorialization in Perspective: Truth, Justice and Memory of Past Repression in the Southern Cone of South America', International Journal of Transitional Justice, vol. 1, 2007.

Nora, P., 'Between Memory and History: Les Lieux de Mémoire', Representations, vol. 26, 1989.

Miller, N. K., 'The Girl in the Photograph: The Visual Legacies of War', in Batchen, G., M. Gidley , N. K. Miller, and J. Prosser (eds), Picturing Atrocity: Photography in Crisis, Reaktion Books, London, 2012.

Minnow, M., Between Vengeance and Forgiveness, Beacon Press, Massachusetts, 1998.

Rush, P. and O. Simic (eds), The Arts of Transitional Justice: Culture, Activism, and Memory after Atrocity, Springer Series in Transitional Justice, vol. 6, Springer, 2014. doi: http://dx.doi.org/10.1007/978-1-4614-8385-4

Segura, M., and H. C. Mack, 'Editorial Note: When Transitional Justice Is Not Enough', International Journal of Transitional Justice, vol. 6, 2012.

Simic, O., 'Memorial Culture in the former Yugoslavia: Mothers of Srebrenica and the Destruction of Artefacts by the ICTY' in Peter Rush and Olivera Simic (eds), The Arts of Transitional Justice: Culture, Activism, and Memory after Atrocity, Springer Series in Transitional Justice, vol. 6, Springer, 2014.

Stover, E., The Witnesses: War Crimes and the Promise of Justice at the Hague, University of Pennsylvania Press, Philadelphia, 2007.

The Prosecutor v. Radislav Krstić, Case IT-98-33, open session 26 July 2000, ICTY

Tochman, W., Like Eating a Stone: Surviving the Past in Bosnia, trans. Antonia Lloyd-Jones, Portobello Books, London, 2008.

Vulliamy, E., 'Afterword' in Emir Suljagić, Postcards from the Grave, Saqi Books, London, 2005.

Williams, P., 'Witnessing Genocide: Vigilance and Remembering at Tuol Sleng and Choeung Ek', in Holocaust and Genocide Studies, vol. 18, no. 2, 2004. doi: http://dx.doi.org/10.1093/hgs/dch063

Wright, R., 'Where are the Bodies? In the Ground', The Public Historian, vol. 32, 2010.

Young, J. E., The Texture of Memory: Holocaust Memorials and Meaning, Yale University Press, New Haven, 1993. 